\title{
感潮域に堆積する有機污泥の還元環境改善技術 の開発 \\ DEVELOPMENT OF A METHOD FOR IMPROVING REDUCED ENVIRONMENT OF THE SLUDGE DEPOSITED IN ESTUARINE REGIONS
}

\author{
TOUCH NARONG ${ }^{1}$ 金城信隆 ${ }^{2} \cdot$ 太力内紘平 $^{2} \cdot$ 中下慎也 $^{3} \cdot$ 日比野忠史 ${ }^{4}$ \\ Narong TOUCH, Nobutaka KINJO, Kohei TACHIUCHI, Shinya NAKASHITA, and \\ Tadashi HIBINO \\ 1正会員 工博 広島大学特任助教 工学研究院 社会環境空間（三739-8527 広島県東広島市鏡山1-4-1） \\ 2学生会員 広島大学 工学研究科 社会基盤環境工学（干739-8527 広島県東広島市鏡山1-4-1） \\ 3 正会員 工博 広島大学助教 工学研究院 社会環境空間（干739-8527 広島県東広島市鏡山1-4-1） \\ 4正会員 工博 広島大学准教授 工学研究院 社会環境空間（干739-8527 広島県東広島市鏡山1-4-1）
}

\begin{abstract}
Laboratory experiments were conducted to propose a microbial fuel cell-based technology for recovering electrons from the sludge deposited in estuarine regions, in order to improve the reduced environment (i.e. removal of hydrogen sulfide " $\mathrm{H}_{2} \mathrm{~S}$ " and redox potential "ORP") of the sludge and the water environment. The results suggested that the electron recovery could perfectly remove $\mathrm{H}_{2} \mathrm{~S}$ from the sludge and increase the ORP of the sludge. By electron recovery, the ORP of overlying water was kept higher and the electrical conductivity was kept lower comparing with those without the electron recovery. These ensure that the electron recovery could also confine the ion diffusion from sludge to overlying water, which lower the aggravation of water environment by the ion diffusion from the deposited sludge.
\end{abstract}

Key Words: Sludge, electron recovery, hydrogen sulfide removal, water environment restoration

\section{1. はじめに}

合流式下水道施設では計画を超える排水量の増大に より，大量の未処理下水が河川や海域に放流されている. この結果感潮域には下水を起源とした有機污泥が堆積し, 底質環境と水環境の悪化を引き起こしている，特に，堆 積した有機污泥内の有機物分解によって強い還元環境が 形成され，悪臭（アンモニアや硫化水素ガス等）や無酸 素水層の発生等の沿岸環境問題を引き起こす主な要因と なっている. 下水が放流され，堆積した有機污泥の分解 に伴ったスカム (浮上有機污泥の塊) の発生（写真-1, 左），東北大震災地における津波堆積物や下水起源の有 機污泥からの悪臭ガスや害虫の発生（写真-1, 右）は生 活を阻害する深刻な問題である. 下水の未処理放流は社 会生活に悪影響を及ぼしているが，下水を全て処理する 場合，莫大な電力と廃棄物（現状でも下水処理には全電 力の $0.7 \%$ 使用と産業廃棄物の 2 割を越える量の污泥が 処理されている）がさらに増えることになる. 地球規模 の環境保全を考えれば，計画を越えて放流される下水等

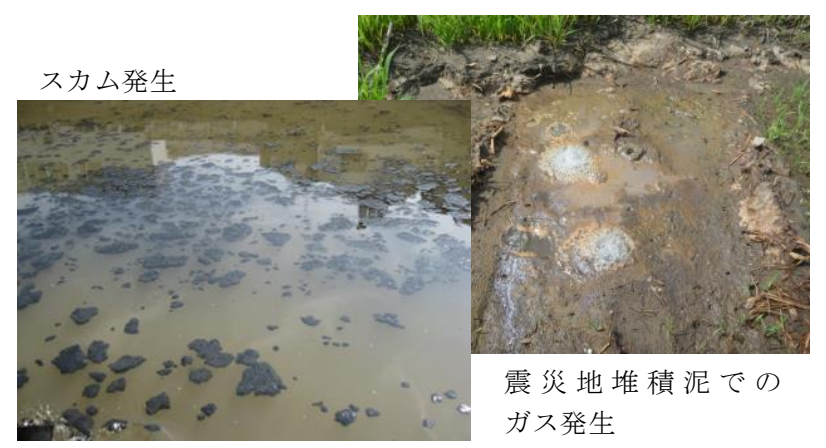

写真-1 有機污泥の分解によるスカムやガスの発生.

による有機污泥の強い還元環境を効率的に改善，特に硫 化水素ガス等による悪臭を解決するための技術開発が必 要である. 流れや微生物等の自然条件を持つ感潮域で放 流下水を適切に処理することができれば経済面のみなら ず，環境負荷の低減効果は極めて大きい. 有機污泥の浄 化には有機物の分解プロセスに直接インパクトを与える 手法が極めて有効である.

近年では下水の新たな浄化技術として, 微生物燃料 電池（MFC）の研究が国内外で進められている. MFC 
表-1 微生物燃料電池による有機物の分解に関する既往研究.

\begin{tabular}{|c|c|c|}
\hline 研究者 & 手法 & 成果 \\
\hline Jung and Regan, 2007 & $\begin{array}{l}\text { 下水起源の污泥にMFCを適用し, アノード電 } \\
\text { 極のbacterial communityを分析し, 微生物の多 } \\
\text { 様性を評価した. }\end{array}$ & $\begin{array}{l}\text { アノード電極付近では, geobacter sulfurreducensが } \\
\text { 支配的に有機物の分解を担っていることが報告され } \\
\text { ている. }\end{array}$ \\
\hline Hong et al., 20082) & $\begin{array}{l}\text { Lake sedimentにMFCを適応し, 堆積物の有機 } \\
\text { 物量(LOI)および酸化還元電位 (ORP)の変化 } \\
\text { によりMFCの効果を現地において評価した. }\end{array}$ & 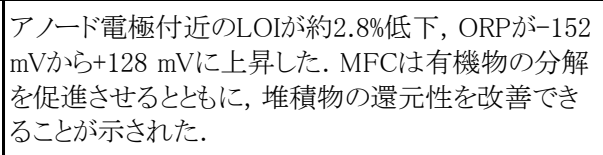 \\
\hline Hong et al., 2010 & $\begin{array}{l}\text { 淡水堆積物を用いて, バイオポリマー, フルボ } \\
\text { 酸, フミン酸に含まれる有機炭素と吸光分析に } \\
\text { よりMFCによる有機物の腐植化が検討された. }\end{array}$ & $\begin{array}{l}\text { 有機物の有機炭素量の減少, および吸光分析結果 } \\
\text { (SUVAの増加等)により有機物の腐植化が促進され } \\
\text { ることが示唆された. }\end{array}$ \\
\hline Morris and Jin, 2012 & $\begin{array}{l}\text { Hydrocarbon-contaminated sedimentにMFCを } \\
\text { 適用し, 有機炭素含有量から有機物の分解を } \\
\text { 評価した. }\end{array}$ & $\begin{array}{l}\text { 適用されないケースに比べてMFCによる有機物の } \\
\text { 分解量が12倍促進されることが有機炭素含有量の } \\
\text { 低下により示された. }\end{array}$ \\
\hline Touch et al., 2014 & $\begin{array}{l}\text { 感潮河川から採取した有機泥にMFCを適用 } \\
\text { L, ORP, 酸素消費能力等から有機泥の性状 } \\
\text { 変化を評価した. }\end{array}$ & $\begin{array}{l}\text { 電子回収により有機泥のORPが上昇することや酸素 } \\
\text { 消費能力が高くなること等により有機物形態の変化 } \\
\text { が確認された. }\end{array}$ \\
\hline
\end{tabular}

は微生物が有機物を嫌気分解する代謝活動から有機物の 化学エネルギーを電気エネルギーに直接変換でき，同時 に有機污泥の浄化が期待できる装置である（図-1）。堆 積物にMFCを適用するSMFC (sediment microbial fuel cells）の効果として, 堆積物の有機物の分解（有機炭素 量や有機物量の低下），還元性の改善，微生物の活性化 (増殖等) が報告されている（表-1）。さらにSMFCが 有機物を酸化させる過程で，下水起源の有機污泥の悪臭 源である硫化水素イオン等の無機物を酸化させているた め，有機污泥の悪臭を除去する技術としても期待できる.

しかしながら，SMFCで回収できる電力が極めて低い ことのから, 本研究では有機污泥から強制的に電子回収 を行い, 有機污泥内の硫化水素イオンの除去，および有 機污泥内の有機物分解を検討寸ることを目的としている. 具体的には，SMFCの技術を用いた有機污泥からの電子 回収による有機污泥間隙水内のイオン濃度, 有機污泥の 燃焼特性，およひ酸化還元状態等の変化を検討寸る. ま た, これらのパラメターの変化に及ぼす有機污泥からの 電子回収条件 (通電量, 回収電流) の効果も検討寸る.

\section{2. 室内実験の概要と条件}

\section{（1）通電方法を変えた微生物燃料電池の性能評価}

\section{a）微生物燃料電池の作成}

体積が約500 $\mathrm{mL}$ 容器の底から高さ $50 \mathrm{~mm}$ まで投入した 有機污泥をアノード層とし，アノード層の上を水道水で 満たして（上層水），分析用ボトルを作成した。ささに 分析用ボトルを $60 \mathrm{~L}$ 水槽内（カソード水）に静置させた

（図-2）。海水よりイオン濃度が小さい水道水を使用し たのは，電子回収による有機污泥から上層水へのイオン 拡散をより明確に検討するためである.アノード電極は $36 \mathrm{~cm}^{2}$ の枚の電極を容器の底から $10 \mathrm{~mm}$ の間隔で有機污 泥内に設置された４枚の電極を設置するのは，電子回

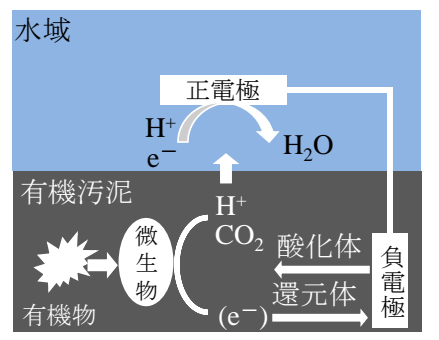

図-1 微生物燃料電池による有機物の分解.

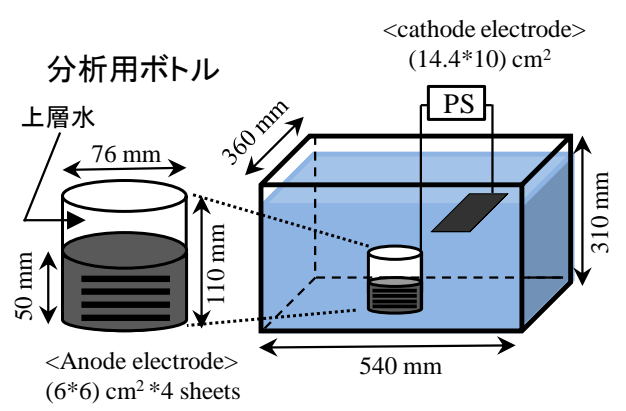

図-2＼cjkstart実験に用いた装置の概略図

収に伴う有機污泥の性状変化を均一にするためである. カソード電極（144 $\mathrm{cm}^{2} の 1$ 枚）は60 L水槽の水面付近に 設置された. 60 L水槽内にカソード電極を設置するのは, 有機污泥からイオン拡散と通電に伴うカソード水質の変 化を低減させるためである. 両電極はポテンショスタッ トまたは外部抵抗と Ni-導線（Nilaco, NI311477）で接 続されている.

\section{b）実験に用いた材料}

アノード層には広島県福山内港に堆積した有機污泥が 用いられた. 使用した有機污泥は下水起源の有機物を主 な有機組成物としている. 現地有機污泥層内では有機物 分解が活発に起こっており, 採取時にはメタンや硫化水 素ガスが発生し，悪臭を放していた。採取した有機污泥 を2 mmふるいに通して, 通過した有機污泥を実験に用 いた. 実験に使用した有機污泥の性状および水道水の水 質は表-2に示されている. 以降に示寸電位は $\mathrm{Ag} / \mathrm{AgCl}$ 
基準とした值である. 表-2に示した有機污泥の電気伝導 率 (EC, Horiba: 3552-10Dで測定) は有機污泥の間隙水の 值であり, 強熱減量 $(\mathrm{LOI})$ は $50^{\circ} \mathrm{C}$ 乾燥した有機污泥を $600^{\circ} \mathrm{C}$ で4時間燃焼させたときの質量の減量割合である. 粒子状炭素含有量 (PCC) は $50^{\circ} \mathrm{C}$ 乾燥した有機污泥を CHNS分析装置 (Pelkin Elmer社製, CHNS/0 2400 II 型) で測定した。電極材料としてカーボンクロス（News Company, PL200-E) を用いている. なお，カーボンク ロスの燃焼により電極性能を向上される7たため, 本研究 ではカーボンクロスを $500^{\circ} \mathrm{C}$ で30分燃焼させた.

\section{c）通電条件の設定とアノード電位変化の評価}

Wang ${ }^{8)}$ (2009) はアノード電位を $200 \mathrm{mV}$ に設定し, 微生物燃料電池を構築することで電気生産細菌の活性化

（電極での電気生産細菌の付着・増殖）に成功した。 こ のことは，電気生産細菌を活性させることによりスター トアップの短縮，すなわち，安定な電力回収への早期移 行を可能に寸ることを示している．この結果を基に，本 研究においても初期のアノード電位が200 mVになるよ うに電流の設定を検討した。 まず，ポテンショスタット （北斗電工，HA-151B）を用いて電流とアノード電位と の関係を検討し，アノード電位を $200 \mathrm{mV}$ に上昇させた 電流 $\left(1 \mathrm{~mA}\right.$ ，電流密度は69.5 mA $\left./ \mathrm{m}^{2}\right)$ を明らかにした。 次に, 有機污泥加ら異なる電流 $(0.54 \mathrm{~mA}, 1 \mathrm{~mA}, 2 \mathrm{~mA})$ と通電条件（表-3）によるアノード電位の経時変化を評 価するとともに, 各々の通電条件による有機污泥の性状 変化を評価する．1 mA（Case 1〜3）と2 mA（Case 5) の通電にはポテンショスタットが用いられ， $0.54 \mathrm{~mA}$

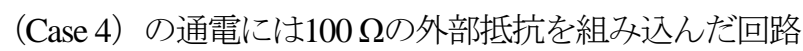
が用いられた。

図-3には異なる通電条件によるアノード電位の変化が

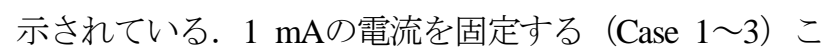
とで, 初期のアノード電位が-322 mVから200〜300 mV まで上昇できた. $0.54 \mathrm{~mA}$ 通電（Case 4）ではアノー ド電位が-150 mVまでの上昇であったのに対し, $2 \mathrm{~mA} の$ 通電（Case 5) では450 mVに上昇した. $1 \mathrm{~mA}$ 設定し たCase 1〜3では電子回収中のアノード電位が実験終了 時に67 mV (Case 1) , $0 \mathrm{mV}$ (Case 2) , $-100 \mathrm{mV}$ （Case 3）まで低下したが，2 mAを設定したCase 5では さらにが高い電位状態 (380 mV以上) で維持されてい る.アノード電位の上昇はアノード電極への電子供給が 不足していることを示している. ただし， $200 \mathrm{mV}$ のア ノード電位では電気生産細菌が得られるエネルギーは大 きいため, 電気生産細菌の活動が活性化し, 電子伝達効 率を向上させる ${ }^{8)}$. したがって, 本実験でのアノード電 位の上昇後の経時的な低下はアノード電極への電気供給 が向上していることを示しており, $1 \mathrm{~mA}$ 電流は電気 生産細菌の活動を活性させていると判断できる.

\section{（2）電子回収に伴う有機污泥性状の評価方法}

本研究では有機物分解によって形成された有機污泥の
表-2 実験に用いた材料の初期性状.

\begin{tabular}{|c|c|c|c|c|c|}
\hline 材料 & $\mathrm{pH}$ & $\begin{array}{c}\text { ORP } \\
{[\mathrm{mV} \text { vs. Ag/AgCl }]}\end{array}$ & $\begin{array}{c}\mathrm{EC} \\
{[\mathrm{mS} / \mathrm{m}]}\end{array}$ & $\begin{array}{c}\mathrm{LOI} \\
{[\mathrm{mg} / \mathrm{g}]}\end{array}$ & $\begin{array}{c}\mathrm{PCC} \\
{[\mathrm{mg} / \mathrm{g}]}\end{array}$ \\
\hline \hline 有機污泥 & 7.02 & -376 & 3450 & 288 & 131 \\
\hline 水道水 & 7.78 & 314 & 9.48 & - & - \\
\hline
\end{tabular}

(注) EC: 電気伝導率, LOI: 強熱減量值, PCC: 粒子状炭素含有量

表-3 有機污泥からの電子回収条件.

\begin{tabular}{|c|c|c|c|c|}
\hline ケース & $\begin{array}{c}\text { 回収量 } \\
{[\mathrm{C}]}\end{array}$ & $\begin{array}{c}\text { 回収電流 } \\
\text { [mA] }\end{array}$ & 回収方法 & 実験期間 \\
\hline Case 1 & 600 & 1 (連続) & \multirow{3}{*}{$\begin{array}{l}\text { ポテンショスタットを用いて } \\
1 \text { mAの電流を固定する. }\end{array}$} & 6d 22h 40min \\
\hline Case 2 & 1200 & 1 (連続) & & $13 \mathrm{~d} 21 \mathrm{~h} 20 \mathrm{~min}$ \\
\hline Case 3 & 1200 & 1 (断続) & & $22 \mathrm{~d} 21 \mathrm{~h} 20 \mathrm{~min}$ \\
\hline Case 4 & 1259 & 0.54 (連続) & $100 \Omega$ 抵抗で連続通電する. & $27 \mathrm{~d} \quad 58 \mathrm{~min}$ \\
\hline Case 5 & 1200 & 2 (連続) & $\begin{array}{l}\text { ポテンショスタットを用いて } \\
2 \text { mAの電流を固定する. }\end{array}$ & $6 \mathrm{~d} 22 \mathrm{~h} 40 \mathrm{~min}$ \\
\hline
\end{tabular}

(注) C: クーロン

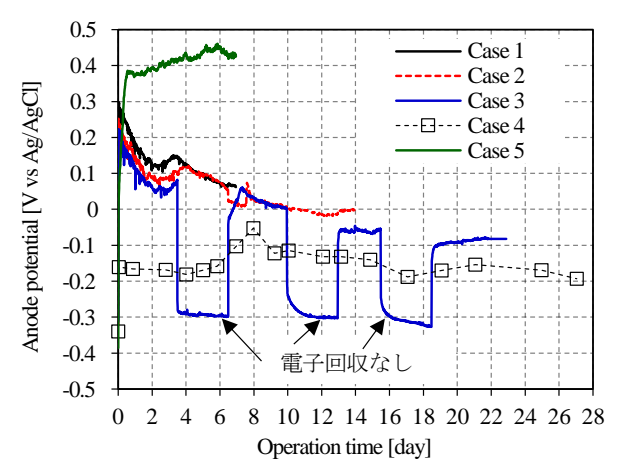

図-3＼cjkstart異なる通電条件でのアノード電位の変化

還元環境を効率に改善することができるとして, 決定し た表-3に示した通電条件（通電量, 回收電流）で検証す る. 検証は通電ケースの実験期間（表-3）に対応する無 通電条件（０Ｃ，C：クーロン）での5つのケース (Control) との比較によって行われた.

異なる通電条件による有機污泥の還元環境の改善評価 は, 通電後の間隙水・上層水のイオン濃度（共立理化研 究所，ラムダー9000で測定），および有機污泥の性状

(pH， ORP，燃焼特性）分析により行われた。 $\mathrm{pH}$ ORPの測定には堀場製作所のD-70シリーズが用いられた。 燃焼特性試験では, 電気マッフル炉（Yamato化学機器, FO610）を用い，乾燥質量に換算して約 $1.5 \mathrm{~g}$ の有機污泥 を50 $\mathrm{C}$ の6時間で乾燥してから，100，200，300，375， 500 と $600^{\circ} \mathrm{C}$ 各温度で4時間燃焼させた。本論文では有 機物の形態を構造が不安定な有機物之腐植性有機物に大 別して扱う. Cuypersら (9)有機物の示差熱から有機物の 特定を試夕ており, 脂肪酸, セルロース等の構造が不安 定な有機物は250 350 $\mathrm{C}$ で最も燃焼し, 腐植性有機物は 370 540ㄷで最も燃燒する結果を得ている.

\section{3. 電子回収による底質環境と水環境の改善効果}

（1）電子回収による有機污泥の還元環境の改善

MFCが適用された堆積物では, 通電に伴う有機物お 
よび無機物（例えば， $\mathrm{HS}^{-}, \mathrm{Fe}^{2+}$ 等）の酸化によって最 終的に堆積物のORPが上昇することになる．この時，酸 化により発生したプロトンのカソード層への拡散が制限 されるため, プロトンが堆積物内に蓄積し, 堆積物の $\mathrm{pH}$ ガ低下していく.

図-4には実験終了時の通電あり・なしのCase 1〜5の $\mathrm{pH} \sim \mathrm{ORP}$ 関係が示されている. 図中の実線は $\mathrm{SO}_{4}{ }^{2-} / \mathrm{H}_{2} \mathrm{~S}$ の酸化還元電位を示している. この図より，1 mA以上 の電流で電子回収する場合はpHの低下とORPの上昇が あり，還元体物質の酸化とプロトンの蓄積が確認できる. 600 Cを回収したCase 1において, pHは7.01（Case 1Control）から6.48まで低下，ORPは-372から-326 mVま で上昇した. ただし，ORPの上昇が $\mathrm{SO}_{4}{ }^{2-} / \mathrm{H}_{2} \mathrm{~S}$ の酸化還 元反応線上にあるため, 有機污泥が酸化状態に移行した とは言えない. 1200 C以上を回収（Cases 2,3,5）すると， $\mathrm{pH}$ は6.35以下まで低下，ORPは-280 mV以上まで上昇し， 有機污泥が酸化状態に移行している.

$1 \mathrm{~mA}$ のase 2 に比べて, $2 \mathrm{~mA}$ Case 5 の $\mathrm{pH}$ 低い (ORPが同程度) のは, Case 5のアノード電位の夕実験 終了まで380 mV以上の高い電位で維持された（図-3） ため, 異なる電子伝達体の酸化反応が生じたと考えられ る. 例えば, $\mathrm{E}^{0}=303 \mathrm{mV}$ vs. $\mathrm{SHE}(\mathrm{pH}=6.2$ では- $294 \mathrm{mV}$ vs. $\mathrm{Ag} / \mathrm{AgCl})$ での $\mathrm{SO}_{4}{ }^{2-} / \mathrm{H}_{2} \mathrm{~S}$ の酸化還元反応（(1)式）では 1モルの電子に対して5/4モルのプロトンが生成される. これに対して, $\mathrm{E}^{0}=1057 \mathrm{mV}$ vs. $\mathrm{SHE}(\mathrm{pH}=6.2 て ゙ は 56 \mathrm{mV}$ vs. $\mathrm{Ag} / \mathrm{AgCl})$ での $\mathrm{Fe}(\mathrm{OH})_{3} / \mathrm{Fe}^{2+}$ の酸化還元反応（(2)式） では1モルの電子に対して3モルのプロトンが生成され， この反応が支配的に生じれば，有機污泥にプロトンが多 く蓄積することになると理解できる.

$\mathrm{H}_{2} \mathrm{~S}+4 \mathrm{H}_{2} \mathrm{O} \Leftrightarrow \mathrm{SO}_{4}^{2-}+10 \mathrm{H}^{+}+8 e^{-}, \quad \mathrm{E}^{0}=303 \mathrm{mV}$

$\mathrm{Fe}^{2+}+3 \mathrm{H}_{2} \mathrm{O} \Leftrightarrow \mathrm{Fe}(\mathrm{OH})_{3}+3 \mathrm{H}^{+}+e^{-}, \mathrm{E}^{0}=1057 \mathrm{mV}$

ここに， $\mathrm{E}^{0}$ は標準還元電位 [vs. SHE]である.
$0.54 \mathrm{~mA}$ 電流で1259 Cを電子回収したCase 4では, pHは1200 Cを回収したCase $20 \mathrm{pH}$ と同程度であるが， ORPの上昇は小さい $(-407 \mathrm{mV}$ に対して $-381 \mathrm{mV})$ 。電 子回収速度 $(0.54 \mathrm{~mA})$ は遅く, 実験期間が長い（約 27 日間) Case 4では，有機物分解の進行とともに電子が生 産されたために, 有機污泥のORPが上昇していないと考 えられる.これらの結果は電子回収量が同じ場合におい ても電子回収方法（異なる回収電流）によって有機污泥 の酸化還元状態が異なることを示している.

以上の結果から，有機污泥の還元状態を酸化状態に 遷移させるには有機物分解からの電子生産量を上回る電 子回収の電流を設定する必要があることがわかる，本実 験条件では，電子回収量が600 C以上，かつ回収電流が 1 $\mathrm{mA}$ （電流密度が $69.5 \mathrm{~mA} / \mathrm{m}^{2}$ ) を設定することで，有機 污泥が酸化状態に移行することを明らかにした.

\section{（2）電子回収による有機污泥の悪臭 $\left(\mathrm{H}_{2} \mathrm{~S}\right)$ 除去}

電子回収に伴う $\mathrm{pH}-\mathrm{ORP}$ 変化は $\mathrm{SO}_{4}{ }^{2-} / \mathrm{H}_{2} \mathrm{~S}$ の酸化還 元反応線の付近にあり（図-4）, アノード電極では主に $\mathrm{H}_{2} \mathrm{~S}$ が酸化されることが推測される，表-4には実験終了 時の間隙水および上層水（図-2）のイオン濃度が示され

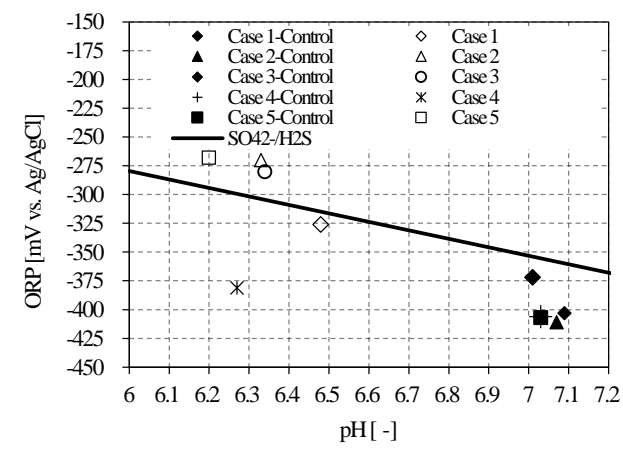

図-4 各ケースの有機污泥のpH ORP関係. ( $\mathrm{pH}$ とORP測定の最大誤差は各々 : $0.015,7.5 \mathrm{mV}$ )

表-4 電子回収に伴う間隙水中, および上層水のイオン濃度の変化.

(一 : 未測定, $\mathrm{H}_{2} \mathrm{~S}, \mathrm{SO}_{4}{ }^{2-}$, 鉄イオンの測定誤差は各々 $, \pm 0.75 \mathrm{mg} / \mathrm{L}, \pm 7 \mathrm{mg} / \mathrm{L}, \pm 0.025 \mathrm{mg} / \mathrm{L}$ でる)

\begin{tabular}{|c|c|c|c|c|c|c|c|c|c|}
\hline \multirow[b]{2}{*}{$\begin{array}{c}\text { Sample } \\
\text { (実験期間 ) }\end{array}$} & \multirow[b]{2}{*}{ 回収量 } & \multicolumn{4}{|c|}{ 間隙水 } & \multicolumn{4}{|c|}{ 上層水 } \\
\hline & & $\begin{array}{r}\mathrm{H}_{2} \mathrm{~S} \\
{[\mathrm{mgL}]}\end{array}$ & $\begin{array}{l}\mathrm{SO}_{4}^{2-} \\
{[\mathrm{mgL}]}\end{array}$ & $\begin{array}{r}\mathrm{Fe}^{2+} \\
{[\mathrm{mgl}]}\end{array}$ & $\begin{array}{c}\mathrm{Fe} \\
{[\mathrm{mg} / \mathrm{L}]}\end{array}$ & $\begin{array}{c}\mathrm{H}_{2} \mathrm{~S} \\
{[\mathrm{mgl}]}\end{array}$ & $\begin{array}{r}\mathrm{SO}_{4}{ }^{2-} \\
{[\mathrm{mgL}]}\end{array}$ & $\begin{array}{r}\mathrm{Fe}^{2+} \\
{[\mathrm{mgL}]}\end{array}$ & $\begin{array}{c}\mathrm{Fe} \\
{[\mathrm{mgL}]}\end{array}$ \\
\hline Sludge-start & & 83.50 & $<10$ & 0.09 & 0.11 & - & - & - & - \\
\hline \multirow{2}{*}{$\begin{array}{c}\text { Case } 1 \\
\text { (6d 22h 40min) }\end{array}$} & $600 \mathrm{C}$ & $<0.05$ & $<10$ & - & - & - & - & - & - \\
\hline & Control & 78.75 & - & - & 0.07 & - & - & - & - \\
\hline \multirow{2}{*}{$\begin{array}{c}\text { Case } 2 \\
\text { (13d 21h 20min) }\end{array}$} & $1200 \mathrm{C}$ & $<0.05$ & 26 & 41.50 & 90.00 & $<0.05$ & 17 & 7.55 & 7.40 \\
\hline & Control & 40.75 & - & - & 0.06 & 17 & 41 & 0.13 & 0.17 \\
\hline \multirow{2}{*}{$\begin{array}{c}\text { Case } 3 \\
(22 \mathrm{~d} 21 \mathrm{~h} 20 \mathrm{~min})\end{array}$} & $1200 \mathrm{C}$ & $<0.05$ & 17 & 82.50 & 86.50 & $<0.05$ & 18 & 2.60 & 2.23 \\
\hline & Control & 8.75 & $<10$ & - & 0.15 & 0.752 & 55 & $<0.05$ & 0.12 \\
\hline \multirow{2}{*}{$\begin{array}{c}\text { Case } 4 \\
\text { (27d 58min) }\end{array}$} & $1259 \mathrm{C}$ & $<0.05$ & $<10$ & 21.75 & 46.50 & $<0.05$ & 19 & 9.15 & 9.85 \\
\hline & Control & 8.7 & $<10$ & - & 0.17 & 3.775 & 41 & 0.13 & 0.15 \\
\hline \multirow{2}{*}{$\begin{array}{c}\text { Case } 5^{\text {(注) }} \\
\text { (6d 22h 40min) }\end{array}$} & $1200 \mathrm{C}$ & $<0.05$ & 65 & 26.75 & 31.50 & $<0.05$ & 26 & 1.65 & 1.35 \\
\hline & Control & 7.375 & 75 & - & 0.14 & 5.1 & 86 & $<0.05$ & $<0.05$ \\
\hline
\end{tabular}

(注) Case 1〜4の実験は同時期に開始したが，Case 5はCase4が終了した後に開始した. Control: 無通電条件のケース 
ている，無通電条件（対照ケース：Control）では実験期 間が長くなると, $\mathrm{H}_{2} \mathrm{~S}$ が減少している. 上層水中に $\mathrm{H}_{2} \mathrm{~S}$ と $\mathrm{SO}_{4}{ }^{2-}$ が確認されたことから， $\mathrm{H}_{2} \mathrm{~S}$ は上層水へ拡散し， 溶存酸素を利用して酸化されることが理解できる，なお， 実験期間が約 27 日間になっても $\mathrm{H}_{2} \mathrm{~S} か ゙$ 完全に酸化されず, 有機污泥の間隙水中に $8.70 \mathrm{mg} / \mathrm{L}$ の $\mathrm{H}_{2} \mathrm{~S}$ が残存した

（Case 4）。これに対して，600 Cを電子回収したCase 1 （実験期間が約7日）は有機污泥内の $\mathrm{H}_{2} \mathrm{~S}$ が検出されな かった（Controlでは $\mathrm{H}_{2} \mathrm{~S}=78.75 \mathrm{mg} / \mathrm{L} ）$. 電子回収した Case 2〜5の上層水において $\mathrm{H}_{2} \mathrm{~S}$ が検出されなかったため, 間隙水の $\mathrm{H}_{2} \mathrm{~S}$ が検出されないのは, $\mathrm{H}_{2} \mathrm{~S}$ はアノード電極 反応により酸化されると推定される. 寸なわち, 電子回 収は $\mathrm{H}_{2} \mathrm{~S} の$ 完全な除去を誘発でき，有機污泥の悪臭を効 率的（短期間）に除去できる技術として期待できる.

全ての通電ケースにおいて $\mathrm{H}_{2} \mathrm{~S}$ は完全に除去されてい る. 特に, $1200 \mathrm{C}$ 回収したCase 2 と Case 3ではpH一 $\mathrm{ORP}$ の変化とともに $\mathrm{SO}_{4}{ }^{2-}$ (酸化体物質) の上昇が確認 され, 有機污泥が $\mathrm{SO}_{4}{ }^{2-} / \mathrm{H}_{2} \mathrm{~S}$ に対して酸化状態にあるこ とを裏付けている. (1)式によれば，1モルの $\mathrm{H}_{2} \mathrm{~S}$ の酸化 では1モルの $\mathrm{SO}_{4}{ }^{2-}$ が生成される. Case 2 では $40.7 \mathrm{mg} / \mathrm{L}$ 以 上の $\mathrm{H}_{2} \mathrm{~S}$ が酸化されるため, $115 \mathrm{mg} / \mathrm{L}$ 以上の $\mathrm{SO}_{4}{ }^{2-}$ が生 成されることになる. しかし, 測定された間隙水内の $\mathrm{SO}_{4}{ }^{2-}$ 濃度が低い状態にある（Case 1 では $\mathrm{SO}_{4}{ }^{2-}$ が検出さ れなかった）。これは，上層水への $\mathrm{SO}_{4}{ }^{2-}$ の拡散が生じ る, または $\mathrm{SO}_{4}{ }^{2-}$ と異なる硫黄形態が形成されるためと 考えられる. 表-4に示寸全ての通電ケースにおいて上層 水には $\mathrm{H}_{2} \mathrm{~S}$ 存在しないが, $\mathrm{SO}_{4}{ }^{2-}$ が存在しており, 有機 污泥から上層水への $\mathrm{SO}_{4}{ }^{2-}$ 拡散が確認できる.

一般的に $\mathrm{SO}_{4}{ }^{2-} / \mathrm{H}_{2} \mathrm{~S}$ の酸化還元反応は，(1)式で表され るが, 実際は $\mathrm{H}_{2} \mathrm{~S}$ の酸化は直接 $\mathrm{SO}_{4}{ }^{2-}$ 一変換されず, 反 応電位によって $\mathrm{S}$ と $\mathrm{SO}_{2}$ が介在する（(3)〜(5)式）。

$$
\begin{array}{ll}
H_{2} S \Leftrightarrow S+2 H^{+}+2 e^{-}, & \mathrm{E}^{0}=0.140 \mathrm{~V} \\
S+2 \mathrm{H}_{2} \mathrm{O} \Leftrightarrow S O_{2}+4 H^{+}+4 e^{-}, & \mathrm{E}^{0}=0.500 \mathrm{~V} \\
\mathrm{SO}_{2}+2 \mathrm{H}_{2} \mathrm{O} \Leftrightarrow S \mathrm{SO}_{4}^{2-}+4 H^{+}+4 e^{-}, & \mathrm{E}^{0}=0.170 \mathrm{~V}
\end{array}
$$

図-3により，1 mA以上の電子を回収した場合，ア ノード電位は通電条件に応じて-150 450 mVの範囲に 変化していることから, $\mathrm{SO}_{4}{ }^{2-}$ 以外の(3)〜(5)式の反応に 応じた硫黄形態 $\left(\mathrm{S}\right.$ と $\left.\mathrm{SO}_{2}\right)$ が有機污泥内に存在する可 能性があると理解できる.

\section{（3）電子回収による水環境の改善}

有機污泥と上層水間に形成される濃度勾配はイオンを 含めた任意の物質を拡散させる．電子回収した場合には 濃度勾配に加えて, 電位分布（電気泳動）が物質を拡散 させる，ここでは，上層水の電気伝導率 $(\mathrm{EC})$ と ORP の変化により電子回収に伴う有機污泥から上層水へのイ オン拡散について述べる。

1200 Cを電子回収したケースと無通電条件ケースの上 層水のECと $\mathrm{pH} 7$ 亿して換算された $\mathrm{ORP}_{7}$ との比較を

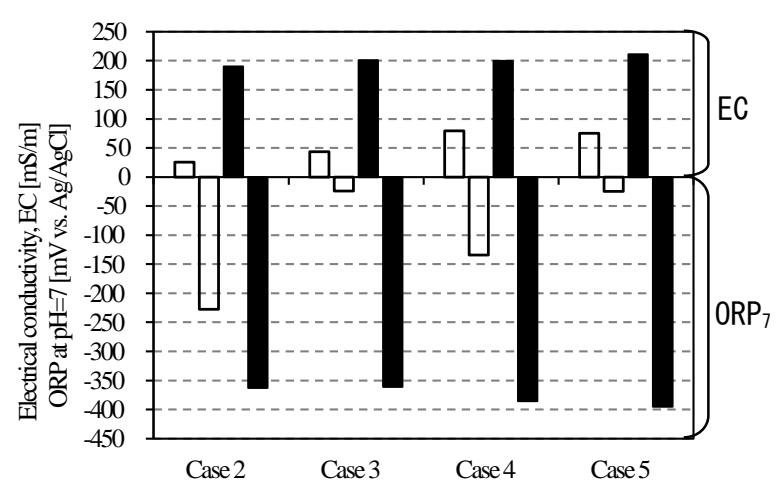

図-5 1200 C回収と無通電時の上層水のECとORP 7. (ECの測定誤差 : $\pm 3 \mathrm{mS} / \mathrm{m}$, 黑棒は無通電条件)

図-5に示した. 有機污泥内からイオンが上層水へ拡散す ると, 電気伝導率が上昇する. 拡散するイオン中に還元 体物質が含有されれば，上層水中の酸素等の酸化体物質 が消費され， $\mathrm{ORP}_{7}$ が低下寸ることになる. 無通電条件 に比べて，電子回収ありの条件では上層水の電気伝導率 が低く, ORP 7 が高い状態にある. 実験期間が約27日間 のCase 4では, 有機污泥からのイオン拡散によってECが $200 \mathrm{mS} / \mathrm{m}$ まで上昇し, $\mathrm{ORP}_{7}$ は-385 mVまで低下してい る（有機污泥のORPと同程度）が，1259 Cを電子回収す ることでECが $80 \mathrm{mS} / \mathrm{m}$ にとどまり， $\mathrm{ORP}_{7}$ が-134 mVに抑 えられている.これは有機污泥内の還元体物質がアノー ド電極で酸化されること（還元体物質の濃度勾配が小さ くなる）ために，カソード層への還元体物質の拡散が制 限されたと考えられる.

以上の結果により電子回収は有機污泥の悪臭（硫化 物）を除去し, 底質環境を改善することに加えて, 上層 水の水質改善を誘発することが明らかになった.

\section{（4）電子回収に伴う有機物の形態変化}

有機污泥の燃焼特性を用いて電子回収に伴う有機污 泥に存在する有機物の形態変化を明らかにする.

腐植性有機物はカルボキシル基やフェノール性水酸 基等を持っており, 粘土鉱物や鉄イオン等の多価金属イ オンと結合して安定な錯体（以降，金属イオン錯体と呼 ぶ）が形成し，有機化合物として有機污泥に存在する. そのため, 腐植性有機物は分解し難く, 微生物に利用し 難くい.

金属イオン錯体の安定度はpHに依存しており, pHの 低下とともに減少していく．金属イオン錯体の破壊が生 じれば，結合された金属イオンと有機物が分裂されるこ とになる. 分裂された有機物が分解し易くなり，有機污

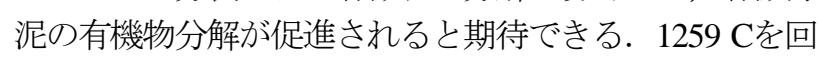
収したCase 4では無通電条件ケース (Control) での鉄イ オン濃度（最大 $0.17 \mathrm{mg} / \mathrm{L}$ ）に比べて鉄イオン濃度が約 274倍 $(46.5 \mathrm{mg} / \mathrm{L})$ まで上昇した（表-4）。鉄イオンの 溶解は, $\mathrm{pH}$ の低下によって有機污泥内に存在する鉄イ オン錯体が破壊されることを裏付けている.このため, 
有機污泥の燃焼特性に変化をもたらすことが予想される.

図-6に1259 Cを電子回収したCase 4の有機污泥の燃焼 特性の変化を示した. 燃焼温度はILの添え字として, 例 えば600 $\mathrm{C}$ までの燃焼割合は $\mathrm{IL}_{600}(\mathrm{mg} / \mathrm{g})$ のように標記 した. 図-6より電子回収によって $\mathrm{IL}_{600}$ の変化がないが, 有機污泥の燃焼特性は変化することがわかる． $\mathrm{IL}_{600}$ の 減少は有機物が無機化（二酸化炭素やメタンが発生）を 示しているが， IL 600 が減少せず，燃焼特性が変わるのは 有機物が無機化に至らず, 有機物の形態が変化すること を示している。図-6では1259 Cを回収すると, $375 \sim 600^{\circ} \mathrm{C}$ で然焼する物質が減少しており，300 375 ${ }^{\circ} \mathrm{C}$ で然焼する物質が増加している。ここでは示していない が，他の電子回収ケースにおいても同様な傾向が確認さ れている。Cuypers ら ${ }^{9}$ の結果（不安定な有機物は $250 \sim 350^{\circ} \mathrm{C}$ で然焼, 腐植性有機物は $370 \sim 540^{\circ} \mathrm{C}$ で燃焼） と照合すれば，電子回収によって不安定な有機物が増加 すると推測される.すなわち，電子回収は結合された金 属イオンと有機物を分裂（有機污泥の有機物形態を変 化）させる働きがあることが理解できる．分裂した有機 物が分解し易くなり, 電子回収は有機污泥の有機物分解 を促進させることも期待できる.

\section{4. まとめ}

本研究では, 有機污泥の還元環境・悪臭を短期的に改 善できる技術を開発すること目的として，強制的に電子 回収による有機污泥の性状変化を室内実験で検討した. 得られた結果を以下にまとめる.

(a) 電子回収は有機污泥内の $\mathrm{H}_{2} \mathrm{~S}$ を完全に除去できると ともにORPを高くすることによって, 有機污泥の還 元環境を改善できる.

(b) 泥層の還元環境を改善することにより上層水のORP を高く，ECを低い状態に維持できることから，電子 回収は有機污泥から上層水へのイオン拡散を制限し， 有機污泥による水質悪化を低減させる.

(c) 電子回収に伴う375 600 ${ }^{\circ} \mathrm{C}$ で然焼する物質が減少, $300 \sim 375^{\circ} \mathrm{C}$ で然焼する物質が増加, さらに鉄イオン が増加することから，電子回収は結合された金属イ オンと有機物を分裂 (有機污泥の有機物形態を変 化）させることができる.

(d) Wangら（2009）の結果と同様に，初期のアノード電 位を200〜300 mVになるように, 電流を $1 \mathrm{~mA}$ (電流 密度は69.5 mA/m²) に設定することで，電気生産細 菌の活動を活性化できることが得られた。

謝辞 : 本研究は日本学術振興会若手研究B（課題番号： 26820204）および科学研究費補助金（課題番号： 266630229）による助成を受けた．ここに記して謝意を 表する.

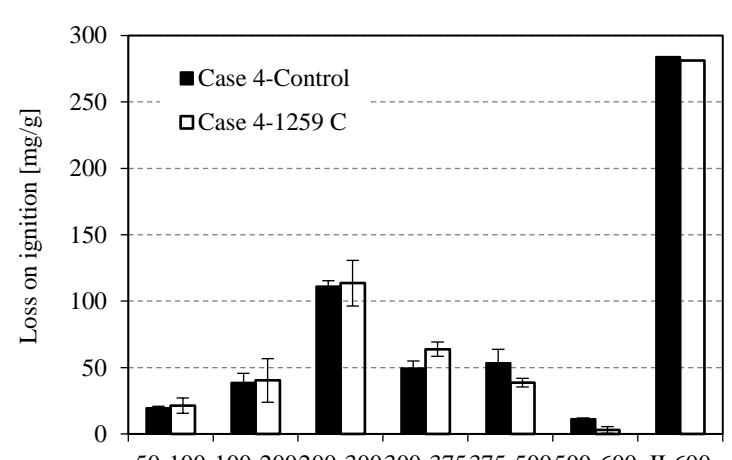

50-100 100-200200-300300-375375-500500-600 IL600 Burning temperature $\left[{ }^{\circ} \mathrm{C}\right]$

図-6 Case 4の有機污泥の燃焼特性の変化.

\section{参考文献}

1) Jung, S., and Regan, J.M.: Comparison of anode bacterial communities and performance in microbial fuel cells with different electron donor. Applied Microbiology and Biotechnology, Vol. 77, pp. 393-402, 2007.

2) Hong, S.W., Kim, H.S., Choi, Y.S., and Chung, T.H.: Field experiments on bioelectricity production from lake sediment. Bulletin of the Korean Chemical Society, Vol. 29, No. 11, pp. 2189-2194, 2008.

3) Hong, S.W., Kim, H.S., and Chung, T.H.: Alteration of sediment organic matter in sediment microbial fuel cells. Environmental Pollution, Vol. 158, pp. 185-191, 2010.

4) Morris, J.M., and Jin, S.: Enhanced biodegradation of hydrocarbon-contaminated sediments using microbial fuel cells. Journal of Hazardous Materials, Vol. 213-214, pp. 474-477, 2012.

5) Touch, N., Hibino, T., Nagatsu, Y., Tachiuchi, K.: Characteristics of electricity generation and biodegradation in tidal river sludgeused microbial fuel cells. Bioresource Technology, Vol. 158, pp. 225-230, 2014.

6) Kaewkannetra, P., Chiwes, W., and Chiu, T.Y.: Treatment of cassava a mill wastewater and production of electricity through microbial fuel cell technology. Fuel, Vol. 90, No. 8, pp. 2746-2750, 2011.

7) Feng, Y., Yang, Q., Wang, X., and Logan, B.E.: Treatment of carbon fiber brush anodes for improving power generation in aircathode microbial fuel cells. Journal of Power Sources, Vol. 195, pp. 1841-1844, 2010.

8) Wang, X., Feng, Y., Ren, N., Wang, H., Lee, H., Li, N., and Zhoa, Q.: Accelerated start-up of two-chambered microbial fuel cells: Effect of anodic positive poised potential, Electrochemica Acta, Vol. 54, No. 3, pp. 1109-1114, 2009.

9) Cuypers, C., Grotenhuis, T., Nierop, K.G.J, Franco, E.M., Jager, A.D., and Rulkens, W.: Amorphous and condensed organic matter domains: the effect of persufate oxidation on the composition of soil/sediment organic matter, Chemosphere, Vol. 48, pp. 919-931, 2002.

(2014. 9. 30受付) 